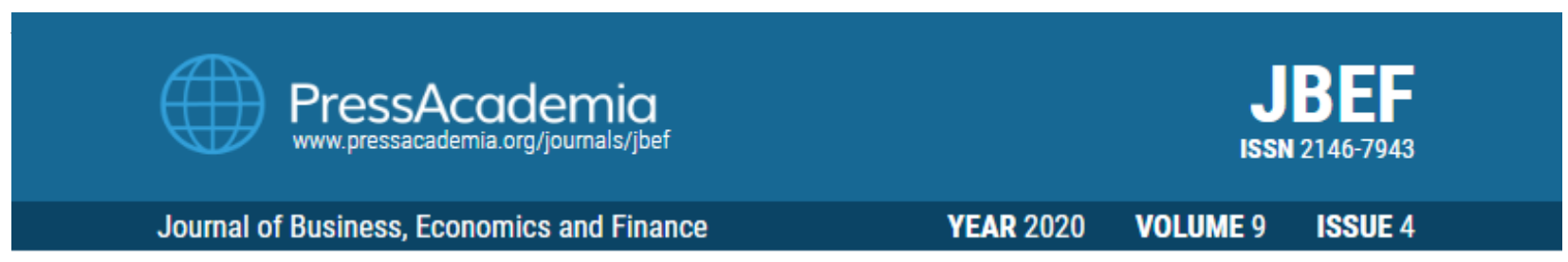

\title{
THE EFFECTS OF LIABILITY DOLLARIZATION ON MANUFACTURING COMPETITIVENESS ${ }^{1}$
}

\author{
DOI: 10.17261/Pressacademia.2020.1315 \\ JBEF- V.9-ISS.4-2020(6)-p.347-355
}

Nilgun Caglarirmak Uslu ${ }^{1}$, Sevcan Kapkara ${ }^{2}$

${ }^{1}$ Anadolu University, Department of Economics, Tepebasi, Eskisehir, Turkey. ncaglarirmak@anadolu.edu.tr, ORCID: 0000-0001-6254-5784

${ }^{2}$ Anadolu University, Department of Economics, Tepebasi, Eskisehir, Turkey. skapkara@anadolu.edu.tr, ORCID: 0000-0002-7864-0505

Date Received: October 22, 2020

Date Accepted: December 15, 2020

To cite this document

Caglarirmak-Uslu, N., Kapkara, S., (2020). The effects of liability dollarization on manufacturing competitiveness. Journal of Business, Economics and Finance (JBEF), V.9(4), p.347-355.

Permanent link to this document: http://doi.org/10.17261/Pressacademia.2020.1315

Copyright: Published by PressAcademia and limited licensed re-use rights only.

\begin{abstract}
Purpose- This study aims to investigate the effect of liability dollarization on competitiveness of sub-sectors operating in Turkish manufacturing industry. Within the scope of the NACE Rev-2 classification, the study used annual data covering the 2008-2016 period for the sub-sectors of the manufacturing industry.

Methodology- A group of econometric tests; fixed effects and random effects approaches have been estimated from panel data methods.

Findings- Variables affecting the manufacturing industry competitiveness were found to be liability dollarization, economic globalization index, energy prices, economic crisis, trade openness, and basket exchange rate. The variable to be used as the "measure of competitiveness" to represent the dependent variable is the ratio of net exports to foreign trade volume. The estimation results show that increase in liability dollarization rate, presence of the economic crisis, and change in energy prices negatively affect competitiveness of sectors, whereas economic globalization index and trade openness have a positive effect on the competitiveness. There is no statistical significant impact of basket exchange rate on competitiveness.

Conclusion- The results of this study indicate that to increase sectoral competitiveness of Turkish manufacturing sector should be increased openness effect and decreased debt dollarization ratio. While sectors increase openness, they can reach new markets and so they can increase their trade activities. But, to increase sectoral economic activity strongly, their fund problems should be solved.
\end{abstract}

Keywords: Competition, liability dollarization, manufacturing industry, panel data analysis JEL Codes: D00, EO0, L60,

\section{INTRODUCTION}

Dollarization, one of the common problems of economies suffering from macroeconomic instability, is a financial phenomenon that occurs when economic units make foreign currency transactions. Liability dollarization refers to foreign currency liabilities of key sectors operating in an economy (Incekara, Mutlugün and Yılmaz, 2017). Especially in cases where the domestic funds are

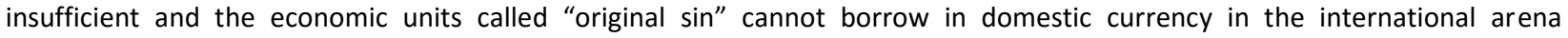
(Eichengreen and Hausmann, 1999), firms that need funding are directed towards foreign currency funds to meet these needs. They prefer to take the risk posed by the exchange rate instead of taking the interest risk due to the debt instruments in local currency. Liability dollarization affects balance sheets through exchange rate volatility and maturity mismatch (Taşseven and Çınar, 2015). In particular, developing country economies with insufficient domestic capital shortage turn to international markets to finance domestic production (Metin-Özcan and Us, 2009). The private sector, to meet the funding needs due to the insufficient domestic savings, has to seek external sources and borrow foreign currency. Thus, the liability dollarization rate increases (Serdengeçti, 2005).

\footnotetext{
${ }^{1}$ This article is supported by Scientific Research Projects which its number is 1906E119.
} 
According to Calvo and Reinhart (2002), the floating exchange rate regime may have a shock-generating feature in the event that firms with mainly domestic currency income have unsecured foreign currency debts. Increases in the real exchange rate affect general financial situation and foreign currency debt sustainability of firms with high foreign currency debt and having income predominantly in domestic currency (Özmen and Yalçın, 2007). In the event that the foreign currency rate on the liability side of the firms' balance sheets is higher than that of the asset side, the firms lose their wealth when the value of domestic currency decreases (Aklan and Nargeleçekenler, 2010). In Turkey, companies mostly prefer foreign currency and short-term debt instruments, which makes them vulnerable to shocks due to exchange and interest rates caused by both currency and maturity mismatch (Kesriyeli, Özmen and Yiğit, 2005). Incekara et al. (2017) state that declines in real exchange rate provide an international competitive advantage and increase the sector income. However, in the case of high liability dollarization in the sector balance sheet, the decrease in real exchange rate may have a negative effect on the balance sheet and this negative effect can outweigh the competitive advantage obtained thanks to the decrease in exchange rate.

Ranciere, Tornell and Vamvakidis (2009) argue that foreign currency borrowing poses systemic risks, but it may also support firms that need funding to meet their needs. "Increases in real exchange rates support the competitiveness of companies in foreign markets within the scope of the influence of competition. However, companies with high liability dollarization in the balance sheet may experience increases in their debt liability, deterioration of their balance sheets, and have payment difficulties" (Alp, 2013).

In this study, how the foreign currency debt that is needed to maintain the economic activities of the sub-sectors playing an active role in the manufacturing industry affects the competitiveness in terms of the developments in exchange rates is investigated. The study is important in terms of examining the competitiveness of the sectors operating in the Turkish manufacturing industry, determining the riskiest sub-sectors due to dollarization, and highlighting the impact of the increases in the dollarization level on the competitiveness of the sector. In the second part of the study, the summary of the relevant literature is included. In the third section, the method, data set, model and estimation results are included. In the last section, results and policy suggestions are presented.

\section{LITERATURE REVIEW}

Bleakley and Cowan (2005) conducted a study including 450 firms operating in chosen Latin American countries (Brazil, Argentina, Chile, Mexico and Colombia) and examined whether exporters with foreign currency borrowing were adversely affected by real exchange rate changes during the period of 1990-1999. In the study, panel data was preferred as the estimation method. The results show that the positive competitive effect balances the negative balance effect caused by the dollar liability.

In a study conducted on Chile, Cowan, Hansen and Herrera (2005) examined the composition of the currency in the assets and liabilities of non-financial companies and the determinants and results of currency mismatches. The results indicate that the balance sheet effect is important, the derivative products isolate firm investments from exchange rate shocks and companies operating in Chile have a tendency to match currency.

Kesriyeli, Ozmen and Yigit (2005) investigated the effects of balance sheet and the causes of the currency composition of the nonfinancial sector in Turkey. Data belonging to 1992-2003 and EGLS and GMM panel data estimators were used in the study. The findings demonstrate that the variables specific to the real sector and the macroeconomic status variables (such as inflation rate and real exchange rate) significantly explain dollarization liabilities of the real sector.

Ozmen and Yalçın (2007) discussed financial structure and liability dollarization-induced fragility of the real sector companies in the global financial dollarization risks in Turkey. The results show that the size of the company is inversely correlated to the financing constraint, small and medium-sized firms are facing more financing constraints, and large-scale firms have high indebtedness levels.

Aklan and Nargeleçeken (2010) investigated the balance sheet effect results of the liability dollarization according to the data of 14 manufacturing industry sub-sectors for the period of 1998-2007, using a dynamic panel data estimator. Findings display that the investments of firms decrease during the periods when the domestic money depreciates, but the investments of firms increase during the periods when the local money appreciates. The other result is that the balance sheet effect is valid in Turkey.

In their studies, Kesriyeli, Ozmen and Yigit (2011) examined the causes, balance sheet effect, and results of liability dollarization of non-financial sector in Turkey. Dynamic panel data method and 1992-2003 period data of 26 non-financial main sectors were used. Findings show that both industry and macroeconomic variables are important in explaining the liability dollarization of the sectors. In addition, it is shown that the liability dollarization and export have a positive correlation and the real exchange rate depreciation has a narrowing effect on investment and profitability for the sectors with a high level of liability dollarization. The 
other result obtained from the study is that the negative balance sheet effect suppresses the positive competitive effect and the liabilities of firms are partially matched with the export income in currency.

In the study of Alp (2013), the effects of the firm-specific and macroeconomic determinants of the liability dollarization of real sector firms and the liability dollarization rate in terms of investments were investigated. The findings show that both firm-specific variables such as "leverage ratio, net tangible assets ratio, export rate, and scale size", and macroeconomic variables such as "inflation, change in real exchange rate, global risk appetite, and share of public sector borrowing in GDP" are significant in explaining liability dollarization.

In their studies including the data of the manufacturing and non-manufacturing sector obtained from balance sheet records of the Central Bank of the Republic of Turkey between 1996 and 2010 and using dynamic panel estimators, Alp and Yalçın (2015) found that liability dollarization positively affects overall company sales and employment growth. However, it is observed that companies with a high liability dollarization rate have a significant decrease in net profit margins in crisis periods.

Gonzales, Micco and Montoya (2015) investigated the relationship between foreign bank penetration and dollarization in the banking sector for the period of 1995-2008 in Latin American countries using unbalanced panel data analysis. The results demonstrate that the dollarization or monetary board reduces transaction costs and facilitates financial integration. Therefore, dollarization has a positive relationship with competition.

Using panel data estimator, Taşseven and Çınar (2015) examined the determinants of the liability dollarization in the real sector in Turkey and its effects on investment during the period of 1996-2013. The results show that the changes in the previous period's liability dollarization rate, leverage ratio, inflation rate, foreign sales, public debt, tangible assets and real effective exchange rates affect the liability dollarization in the long run in an increasing direction, while increases in the firm size and stock market fluctuations affect the dollarization in a decreasing way. It is also seen that the liability dollarization rate affects real investments positively.

Using the data set and panel data GMM estimator, Aydın, Ekinci and Tüzün (2017) investigated the determinants of the liability dollarization and balance sheet status of the Turkish manufacturing sectors between 2008 and 2015. The aim of the study was to discuss the profitability of the real sector in terms of political instability and exchange rate changes within the framework of international competitive advantage and balance sheet effect. The study concludes that the variable defined as the competitive effect positively affects the active profitability.

In another study investigating the effects of liability dollarization on the growth of the manufacturing industry, Incekara, Mutlugun and Yilmaz (2017) discussed the effects of real exchange rate changes on the balance sheets and growth of firms operating in the sector. In the study covering 15 manufacturing sub-sector data from 1998-2013, panel data estimation method was used. The results indicated that real exchange rate declines have a positive effect on firm competition and the effect of liability dollarization may change either positively or negatively depending on the firm structure. It is concluded that in the intervals in which the liability dollarization coefficient is positive up to $34 \%$, sales and growth of the manufacturing industry increase, and in the intervals with $34-85 \%$, the net sales growth rate of firms' decrease, and the growth of the firms is positively affected when the liability dollarization is greater than $85 \%$.

Yolcu-Karadam (2018) evaluated the liability dollarization and export performances of the Turkish manufacturing sub-sectors against the developments in the exchange rate within the scope of the ISIC Rev. 3 classification. As a result of the examinations, it is observed that intermediate goods are both among the low export sectors and the riskiest sectors due to the high dollarization of liabilities.

Karamollaoğlu and Yalçın (2019) examined the relationship between real exchange rates and export share of manufacturing firms in Turkey between 2002 and 2010 using data and panel data estimators. The results show that the depreciation of the Turkish Lira supports the foreign competitiveness of the companies.

\section{METHOD, DATA AND MODEL}

In this study, fixed and random effects estimators of panel data estimators were used due to a large number of units and multiple time dimensions. Since the panel data method has both time and section data features, panel data estimation results yield more information compared to time series and section data analysis. Panel data consists of $\mathrm{N}$ units and T observations. The panel data set used in this study includes 23 manufacturing sub-sectors and 9-year time dimensions.

Data sets regarding the Turkish manufacturing industry sub-sectors, covering the annual data between 2008 and 2016 , were obtained from sectoral balance sheet information of Central Bank of the Republic of Turkey (CBRT) and Turkey Statistical Institute 
(TSI). The reason for choosing the review period as 2008-2016 was that the data set related to foreign currency use was accessible for this period within the scope of the NACE Rev-2 classification. All statistical outputs in the study were obtained through the STATA 15.0 package program.

Table 1: Liability Dollarization Rate and Competitiveness Index of the Manufacturing Industry Sub-Sectors (2016)

\begin{tabular}{|c|c|c|}
\hline Manufacturing Sub-Sectors & Liability Dollarization & Competitiveness Index \\
\hline Food Industry & 0.47 & 0.33 \\
\hline Beverage Industry & 0.45 & -0.19 \\
\hline Tobacco Industry & 0.29 & 0.58 \\
\hline Textile Industry & 0.7 & 0.41 \\
\hline Clothing Industry & 0.65 & 0.71 \\
\hline Leather Industry & 0.44 & -0.04 \\
\hline Wood, Wood Products and Mushroom Industry & 0.69 & -0.25 \\
\hline Paper Industry & 0.65 & -0.29 \\
\hline Printing And Reproduction Of Registered Media & 0.30 & -0.41 \\
\hline Coking Coal And Refined Petroleum Industry & 0.66 & -0.5 \\
\hline Chemicals and Chemical Products Industry & 0.73 & -0.6 \\
\hline $\begin{array}{l}\text { Basic Pharmaceutical Products and Pharmaceutical Related } \\
\text { Materials Industry }\end{array}$ & 0.47 & -0.69 \\
\hline Rubber and Plastic Products Industry & 0.65 & 0.13 \\
\hline Other Non-Metallic Mineral Products Industry & 0.54 & 0.33 \\
\hline Basic Metal Industry & 0.87 & -0.11 \\
\hline $\begin{array}{l}\text { Fabricated Metal Products Manufacturing (Except Machinery and } \\
\text { Equipment) Industry }\end{array}$ & 0.59 & 0.14 \\
\hline $\begin{array}{l}\text { Manufacture of Computers, Electronic and Optical Products } \\
\text { Industry }\end{array}$ & 0.78 & -0.75 \\
\hline Electrical Equipment Industry & 0.64 & 0.06 \\
\hline Machinery and Equipment (Not Classified Elsewhere) Industry & 0.69 & -0.44 \\
\hline Motorized Land Vehicle, Trailer And Semi-Trailer Industry & 0.81 & -0.01 \\
\hline Other Transportation Vehicles Industry & 0.92 & -0.45 \\
\hline Furniture Industry & 0.45 & 0.60 \\
\hline Others & 0.68 & 0.14 \\
\hline
\end{tabular}

Source: Prepared with the data obtained from CBRT and TSI.

Table 1 shows the liability dollarization rate and competitiveness index information of the manufacturing industry sub-sectors in 2016. The top three sectors with the highest liability dollarization rate are other transportation vehicles industry with $92 \%$, the basic metal industry with $87 \%$, and motor vehicles, trailers (trailers) and semi-trailer manufacturing sub-sectors with $81 \%$. The three sectors with the lowest dollarization rate are the manufacturing of tobacco products with $29 \%$, printing and reproduction of registered media with $30 \%$, and the production of leather and related products with $44 \%$.

Variables used in the study:

Competitiveness index (C) was used as a dependent variable in models. Sectoral export and import data (in dollars) used to calculate the index were obtained from Turkey Statistical Institute (TSI) and converted into the Turkish Lira at the foreign exchange rate. This index value was calculated as shown in equation number 1, inspired by Kılıçaslan and Temurov (2016).

$C=\frac{\text { Total Exports of Sectors-Total Imports of Sectors }}{\text { Total Exports of Sectors+Total Imports of Sectors }}$ 
Liability dollarization rate (DD) was calculated as shown in equation 2 . The ratio of cash loans used by the sectors in foreign currency to total loans was calculated following the studies of Taşseven and Çınar (2015), Alp and Yalçın (2015), and Incekara and Mutlugün and Yılmaz (2017). The liability dollarization rate is expected to have a negative impact on the sector's competitiveness. The data used in calculating the dollarization rate was obtained from the CBRT Real Sector Statistics archive.

$\mathrm{DD}=\frac{\text { Cash Loans Used by Sectors in Foreign Currency }}{\text { Total Cash Loans Used by Sectors }}$

Economic globalization index (EGI) is a data published by the KOF Swiss Economic Institute for Turkey. Yurttançıkmaz, Kabadayı and Emsen (2014), examining the growth effects of the globalization index and the competitiveness index, used the globalization index variable. It includes two globalization indices as commercial and financial globalization. Commercial globalization includes trade in goods and services and commercial partner diversification. Financial globalization includes foreign direct investments, portfolio investment, international debt, international reserves and international income payments. The expected impact of the globalization index on competitiveness is positive.

The variable was calculated as the ratio of sectoral exports to country income (XGDP). Data of the manufacturing sector sub-sectors (in dollars) were obtained from TSI. Data regarding the gross domestic products (current prices, US Dollars) were obtained from the World Bank. The variable was calculated as in equation 3.

$\mathrm{XGDP}=\frac{\text { Export of Manufacturing Sector Sub-Sectors }}{\text { Gross Domestic Product }}$

This rate shows the rate of joining and benefiting from the division of labor, which is formed in the world economy in the production of goods and subject to commercial activities. However, since the sector is calculated using export values, there is a rate of participation and utilization in the division of labor across the country. It is expected that the ratio of exports to GDP exerts a positive effect on competitiveness.

The exchange rate (REER) represents the basket exchange rate. It is calculated by taking the arithmetic mean of Dollar / Turkish Lira and Euro / Turkish Lira exchange rates. The equation is shown below

$\operatorname{REER}=\frac{(1 \mathrm{USD} / \mathrm{TL}+1 \mathrm{Euro} / \mathrm{TL})}{2}$

Exchange rate may have a positive or negative effect on competitiveness. A high level of exchange rates increases the competitiveness of the firms with exporter structure and ensures the balance of payments to surplus. Another effect is that for companies using imported inputs mainly, provided that the exchange rate is high, the cost of imported goods increases and therefore, the high exchange rate decreases the competitiveness of the sectors (Yurttançıkmaz, 2014).

Energy Price (OIL) data, obtained from the CBRT, are the crude oil and natural gas price (Domestic Producer Prices) (2003 $=100$ ) (TSI) (NACE REV.2)) percentage change rate. The increase in energy prices is expected to weaken the sector's competitiveness.

CRISIS is a dummy variable added to the model to measure the impact of the 2008 crisis. It became " 1 " in 2008, 2009, 2010,2011 and 2012 and " 0 " in other years. The expected impact of the crisis impact on the sector's competitiveness is negative.

Various models have been developed to measure the effect of the liability dollarization of the sectors on competitiveness. These models are:

$$
\begin{aligned}
& \mathrm{C}_{\mathrm{i}, \mathrm{t}}=\beta_{1}+\beta_{2} \mathrm{DD}_{\mathrm{i}, \mathrm{t}}+\beta_{3} \mathrm{EGI}_{\mathrm{i}, \mathrm{t}}+\beta_{4} \mathrm{XGDP}_{\mathrm{i}, \mathrm{t}}+\beta C R I S I \mathrm{~S}_{i, \mathrm{t}}+\mathrm{u}_{\mathrm{i}, \mathrm{t}} \\
& \mathrm{C}_{\mathrm{i}, \mathrm{t}}=\beta_{1}+\beta_{2} \mathrm{DD}_{\mathrm{i}, \mathrm{t}}+\beta_{3} \mathrm{OIL}_{\mathrm{i}, \mathrm{t}}+\beta_{4} \mathrm{XGDP}_{\mathrm{i}, \mathrm{t}}+\mathrm{u}_{\mathrm{i}, \mathrm{t}} \\
& \mathrm{C}_{\mathrm{i}, \mathrm{t}}=\beta_{1}+\beta_{2} \mathrm{DD}_{\mathrm{i}, \mathrm{t}}+\beta_{3} \mathrm{REER}_{\mathrm{i}, \mathrm{t}}+\beta_{4} \mathrm{XGDP}_{\mathrm{i}, \mathrm{t}}+\mathrm{u}_{\mathrm{i}, \mathrm{t}}
\end{aligned}
$$

In these models, $\mathrm{i}$ indicates the horizontal section as the sub-sector and $\mathrm{t}$ indicates the time dimension. $\beta$ coefficients are the parameters to be estimated. $U$ is the error term. The competitiveness index variable is the dependent variable of the models. All variables except this are independent variables.

\section{FINDINGS}

Models 5, 6 and 7 were created to investigate the effect of liability dollarization on competitiveness. Descriptive statistics for the variables used in these models are shown in table 2 and the econometric estimation results of the models are shown in table 3. 
Table 2: Summary Statistics

\begin{tabular}{llllll}
\hline Variables & Observation & Mean & Standard Deviation & Minimum & Maximum \\
\hline Year & 207 & - & - & 2008 & 2016 \\
\hline C & 207 & -0.07868 & 0.39303 & -0.8185 & 0.72783 \\
\hline DD & 207 & 0.6199 & 0.1689 & 0.0867 & 0.9755 \\
\hline OIL & 207 & 8.4911 & 27.0766 & -34.5 & 48.96 \\
\hline EGI & 207 & 54.0666 & 1.1766 & 52.5 & 56.3 \\
\hline REER & 207 & 2.2377 & 0.5050 & 1.6 & 3.19 \\
\hline XGDP & 207 & 0.0066 & 0.0064 & $5.72 \mathrm{e}-06$ & 0.0333 \\
\hline CRISIS & 207 & 0.5555 & 0.4981 & 0 & 1 \\
\hline
\end{tabular}

In table 2, information regarding the number of observations of the data set, the year interval, the mean, minimum and maximum values of the variables and standard deviation are given. Used total observation number is 207 and examined period is from 2008 to 2016. Other statistics shows individually statistics of each variables.

Table 3: Effect of Liability Dollarization on Manufacturing Sector Competitiveness (2008-2016)

\begin{tabular}{lllllll}
\hline \multicolumn{7}{c}{ Dependent Variable: Competitiveness Index } \\
\hline Models & \multicolumn{2}{c}{ Model 1 } & \multicolumn{3}{c}{ Model 2 } & \multicolumn{3}{c}{ Model 3 } \\
\hline Variables & FE & RE & FE & RE & FE & RE \\
& (Robust) & (Robust) & (Robust) & $\begin{array}{l}\text { (Robust) } \\
\text { (Robust) }\end{array}$ & (Robust) \\
\hline DD & $-0.1488^{*}$ & $-0.1541^{*}$ & $-0.1392^{* *}$ & $-0.1455^{*}$ & $-0.1482^{*}$ & $-0.1542^{*}$ \\
& $(0.008)$ & $(0.002)$ & $(0.011)$ & $(0.003)$ & $(0.004)$ & $(0.001)$ \\
\hline EGI & $0.0146^{* *}$ & $0.0146^{*}$ & - & - & - & - \\
& $(0.015)$ & $(0.009)$ & & & & \\
\hline OIL & - & - & $-0.0006^{* *}$ & $-0.0006^{*}$ & - & - \\
& & & $(0.014)$ & $(0.008)$ & & \\
\hline XGDP & $24.779 *$ & $24.281^{*}$ & $26.296^{*}$ & $25.581^{*}$ & $25.902 *$ & $25.240^{*}$ \\
& $(0.002)$ & $(0.000)$ & $(0.004)$ & $(0.001)$ & $(0.003)$ & $(0.001)$ \\
\hline REER & - & - & - & - & 0.0258 & 0.0258 \\
& & & & & $(0.216)$ & $(0.203)$ \\
\hline CRISIS & -0.0319 & -0.0319 & - & - & - & - \\
& $(0.120)$ & $(0.106)$ & & & & \\
\hline Fixed Term & $-0.9243^{*}$ & $-0.9150^{*}$ & $-0.1599^{* *}$ & -0.1477 & $-0.2150^{*}$ & - \\
& $(0.006)$ & $(0.006)$ & $(0.038)$ & $(0.108)$ & $(0.018)$ & $0.2033^{* * *}$ \\
& & & & & & $(0.054)$ \\
\hline Probability & 0.0001 & 0.0000 & 0.0001 & 0.0000 & 0.000 & 0.000 \\
Value & & & & & & \\
\hline
\end{tabular}

Note: FE represents fixed effects and RE represents random effects models. The probability value shows the F probability for the FE model and the Wald test probability for the RE model. * $1 \%, * * 5 \%$ and ${ }^{* * *} 10 \%$ express statistical significance.

In all three models estimated using fixed and random effects estimators, all independent variables are statistically significant. According to model 1 , both the dollarization rate and the crisis dummy variable, which shows the effect of the 2008 crisis, negatively affect the competitiveness index. The ratio of exports to GDP, which represents the economic globalization index and foreign openness, is statistically significant and has a positive effect on competitiveness. According to model 2 , both the dollarization rate and the percentage change in energy prices negatively affect the competitiveness index, while the ratio of exports to GDP positively affects the competitiveness index. According to model 3 , the dollarization rate negatively affects the competitiveness index, but the ratio of exports to GDP positively affect the competitiveness index. The basket exchange rate doesn't have statistically significant effect on the competitiveness index.

The estimation gives consistent results with the expected signs of the effect of variables on competitiveness. The liability dollarization rate weakens the competitiveness of the manufacturing industry sub-sector due to exchange rate, interest payments, and balance sheet mismatch. Basket exchange rate has a positive effect on the competitiveness of the manufacturing industry 
sub-sectors. This positive effect is thought to be due to the dominant effect of exporters from the sub-sectors of the manufacturing industry.

Porter (1990) argues that economic crises, which are considered as luck factors among the factors affecting national competitiveness, have a negative effect on competitiveness as they are a cost increasing factor for firms. The estimation results support this view of Porter. It was observed that the 2008 crisis had a weakening effect on competitiveness in the manufacturing industry sub-sector. As an oil importing country, a rise in energy prices in Turkey creates an additional cost to the industry because it will increase inflation. The estimation results confirm this statement. The increase in energy prices has a weakening effect on sectoral competitiveness.

Globalization is a driving force in improving competitiveness (OECD, 1996). Globalization supports the increase of international commercial activities. Companies that interact with the world may lose their ability to compete if they cannot follow the developments and fail to incorporate innovations. These companies may have difficulty in maintaining their continuity and in the case of failing, they may have to withdraw from the market. Increasing the market share and product diversity that is effective in increasing the globalization competitiveness offers an opportunity for a cheaper production with a shorter time span. In addition, it provides benefits such as learning technologies and incorporating this technological information into their production processes. Economic globalization is expressed as the economic integration of the world by making goods, services, labor and capital roaming faster and easier between countries, by increasing the barriers such as customs walls, tariffs, quotas and capital restrictions that separate the economies of the country from each other (Adıgüzel, 2013). The estimation results obtained in this study show that the economic globalization index increases the competitiveness of the sub-sectors of manufacturing. Yurttançıkmaz et al. (2014) added the share of exports in GDP to their study to represent the trade openness of the economy. In the statistical results they obtained, the authors reveal that the deepness in the openness dimension supports the competitiveness. In our study, it is seen that the ratio of sector exports added to the model as an indicator of the trade openness of the sectors to GDP positively affects the competitiveness index. This result supports the result obtained from the studies of Yurttançıkmaz et al. (2014).

\section{CONCLUSION}

In this study, the effect of liability dollarization on the competitiveness of the manufacturing industry sub-sectors between 2008 and 2016 was analyzed using panel data and fixed and random effects estimators. The estimation results obtained show that the increase in liability dollarization rate and energy prices and the effect of the economic crisis weaken the competitiveness of manufacturing industry sub-sectors, but the economic globalization index and the ratio of exports to GDP that is used as an indicator of trade openness and exchange rate support the competitiveness.

In economies with low saving rates, it is inevitable for the economic units to borrow in foreign currency to ensure the continuity of production and investment activities and to increase their commercial activities. However, there are some disadvantages of such fund use besides its advantages such as supporting investment and production activities. These are exchange rate risk and interest cost. In particular, excessive volatility affects the economic progress and decisiveness of the sectors, as the economies whose foreign currency income cannot meet their foreign currency debt may be unprotected against foreign exchange risk. The economic globalization index, which also reflects the effect of globalization, and the fact that the openness variables have a positive effect on competitiveness are indicators that the increase in international commercial activities strengthens their competitiveness capabilities.

It is seen that the dollarization of the manufacturing sector in Turkey decreased between 2008 and 2010 whereas it increased in the 2010-2014 period. As of 2014, it has had an upward trend. The competitiveness index value of the sector decreased between 2009 and 2011, and since then, it has generally shown an increasing trend. In 2016, according to the results of the liability dollarization rate calculated as the share of the sum of cash loans used in foreign currency in total cash loans, the sector of other transportation vehicles, which are among the sub-sectors of the manufacturing industry, was $92 \%$ dollarized. Compared to other sectors, it is the sector with the highest fragility due to the highest exchange rate and interest risk and the high amount of foreign currency debts. The sector with the lowest dollarization rate is the "tobacco product manufacturing" sector with $29 \%$. The sector with the highest competitive power index value is the "manufacturing of clothing" sector with an index value of 0.71 . The sector with the lowest competitiveness index is the "manufacturing of computers, electronic and optical products" sector with an index value of -0.75 .

Sectors with a tendency to borrow in foreign currencies should balance their foreign currency income and expenses. Matching currency in assets and liabilities of the firm may have effects such as an increase in debts, creating new investments and profit. Firms can affect their competitiveness with their current and future decisions, considering the overall economic situation. The fact that the sector has a strong financial structure is of great importance to survive during the crises that are likely to occur. 
Considering the findings of this study, it is recommended to decrease the liability dollarization rate in the manufacturing industry sectors and increase the sector's competitiveness for a stronger economy. Accordingly, the domestic saving rate should be increased and sectoral funding needs should be directed from foreign currency sources to domestic currency. Thus, sectoral fragility caused by dollarization can be reduced. In addition, in the case of high liability dollarization, the risk of failing to repay their debts also increases. Failure to repay the debts on time distorts the foreign currency income and balance of the banks or other intermediary institutions that these sectors borrow. Foreign currency debts, a risk factor for both the financial and nonfinancial sectors, are recommended to be decreased by increasing the trust in domestic money, ensuring macroeconomic stability and creating an environment of confidence by eliminating economic uncertainties.

\section{REFERENCES}

Aklan N and Nargeleçekenler M (2010). Yükümlülük Dolarizasyonu ve Bilanço Etkisi: Türkiye Üzerine Bir Analiz. i. Ü. Siyasal Bilgiler Fakültesi Dergisi, 43, 177-204, https://dergipark.org.tr/tr/download/article-file/5272.

Alp, B. (2013). Türkiye'deki Reel Sektör Firmalarında Borç Dolarizasyonu ve Reel Kur Değişimlerinin Bilanço Etkisi. TCMB Uzman Yeterlilik Tezi.

Alp, B. and Yalçın, C. (2015). Türkiye'de Şirketlerin Borç Dolarizasyonu ve Büyüme Performansı. TCMB Çalışma Tebliği, N: 15/01,https://www.tcmb.gov.tr/wps/wcm/connect/c8b76887-0ede-4049-9744a02bdf149d43/bengualp.pdf?MOD=AJPERES\&CACHEID=ROOTWORKSPACE-c8b76887-0ede-4049-9744-a02bdf149d43-m3fBab9

Aydın, Ü., Ekinci, R. and Tüzün, O. (2017). Türkiye'deki Reel Sektörün Finansal Yapısı: Kur Değişimlerinin ve Politik İstikrarsızlığın İmalat Sanayi Üzerine Etkisi. 3rd SCF International Conference on "Economic and Social Impacts of Globalization". Proceeding Book, 5-14, http://www.scfconferences.com/wp-content/uploads/2019/07/3.SCF-INTERNATIONAL-CONFERENCE-PROCEEDINGS.pdf\#page=11

Bleakley, H and Cowan K (2005). Corporate Dollar Debt and Deprectiations: Much Ado About Nothing?. Inter-American Development Bank Research Department Working Paper No: 532, https://www.econstor.eu/bitstream/10419/88075/1/idb-wp 532.pdf.

Calvo, G. and Reinhart, C.M. (2002). Fear of Floating. Quarterly Journal of Economics, 117 (2), 379-408, https://www.nber.org/papers/w7993.pdf.

Chang, R. and A. Velasco (2004). Balance Sheets and Exchange Rate Policy. The American Economic Review, 94(4), 1183-93, https://www.nber.org/papers/w7840.pdf.

Cowan, K., Hansen, E., and Herrera, L. O. (2005). Currency mismatches, balance-sheet effects and hedging in Chilean non-financial corporations. Balance-Sheet Effects and Hedging in Chilean Non-Financial Corporations IDB Working Paper, 432, https://publications.iadb.org/publications/english/document/Currency-Mismatches-Balance-Sheet-Effects-and-Hedging-in-Chilean-NonFinancial-Corporations.pdf.

Eichengreen, B. and Hausmann, R. (1999). Exchange Rates and Financial Fragility. Federal Reserve Bank of Kansas City's Conference on Issues in Monetary Policy, https://www.nber.org/papers/w7418.pdf.

Gonzalez, A., Micco, A. and Montoya, A. (2015). Dollarization, Foreign Ownership, and Competition in the Banking Industry in Latin America. Emerging Markets Finance and Trade, 51(1), 90-107, DOI: 10.1080/1540496X.2015.998074.

https://kof.ethz.ch/en/forecasts-and-indicators/indicators/kof-globalisation-index.html

http://www.oecd.org/

http://www.oecd.org/

http://www.tcmb.gov.tr

İncekara, A., Mutlugün, B. and Aksöz Yılmaz, H . (2017). Borç Dolarizasyonunun Türk İmalat Sanayi Sektörü Büyümesi Üzerine Etkisi. İktisat Politikası Araştırmaları Dergisi, 4 (1), 16-38, https://dergipark.org.tr/tr/download/article-file/271599

Karadam, D. Y. (2018). Effects Of Real Depreciatıons On Turkısh Manufacturıng Industry: Fınancıal Channel. Institutions, Development and Economic Growth, 11-22.

Karamollaoğlu, N., and Yalçin, C. (2019). Exports, real exchange rates and dollarization: empirical evidence from Turkish manufacturing firms. Empirical Economics, 1-31, https://link.springer.com/content/pdf/10.1007/s00181-019-01733-1.pdf.

Kesriyeli, M., Özmen, E. and Yiğit, S. (2005). Corporate Sector Debt Composition and Exchange Rate Balance Sheet Effect in Turkey. Central Bank of Turkey, Research and Monetary Policy Department, WP No. 05/16, https://www.tcmb.gov.tr/wps/wcm/connect/9eacefa5-e2ee-44d3-a3009fe08184cf12/WP0516ENG.pdf?MOD=AJPERES\&CACHEID=ROOTWORKSPACE-9eacefa5-e2ee-44d3-a300-9fe08184cf12-m3fw5MS

Kesriyeli M., Özmen E. and Yiğit S. (2011). Corporate sector debt composition and Exchange rate balance sheet effect in Turkey. Applied Economics, 43(30), 4741-4747, https://www.tandfonline.com/doi/full/10.1080/00036846.2010.498353. 
Kilıçarslan, Y. and Temurov, I. (2016). Import Substitution, Productivity and Competitiveness: Evidence From Turkish and Korean Manufacturing Industry. Optimum Journal of Economics and Management Sciences, 3(2), 67-83, https://dergipark.org.tr/tr/download/article-file/222756

Metin-Özcan, K. and Us, V. (2009). What drives dollarization in Turkey?. Journal of Economic Cooperation and Development, 30(4),29-50, http://repository.bilkent.edu.tr/bitstream/handle/11693/22606/What\%20drives\%20dollarization\%20in\%20Turkey.pdf?sequence=1\&isAllowed= $\underline{y}$.

Özmen E. and Yalçın C. (2007). Küresel Finansal Riskler Karşısında Türkiye'de Reel Sektör Finansal Yapısı ve Borç Dolarizasyon. TCMB Çalışma Tebliği No: 07/06, https://www.tcmb.gov.tr/wps/wcm/connect/de3ade1c-8a57-4787-b8a8-

18af2a20dc34/WP0706.pdf?MOD=AJPERES\&CACHEID=ROOTWORKSPACE-de3ade1c-8a57-4787-b8a8-18af2a20dc34-m3fw5Pe

Ranciere, R., Tornell, A. and Vamvakidis, A. (2009). Currency Mismatch and Systemic Risk in Emerging Europe, Economic Policy CEPS and CES and MSH 25, 597-658, https://doi.org/10.1111/j.1468-0327.2010.00251.x.

Serdengeçti,S.(2005).Dolarizasyon/TersDolarizasyon, Ekim,Eskişehir,https://www.tcmb.gov.tr/wps/wcm/connect/5b404bcd-6e72-415d-a65691da6db0cc6e/sunumeskisehir.pdf?MOD=AJPERES\&CACHEID=ROOTWORKSPACE-5b404bcd-6e72-415d-a656-91da6db0cc6e-m3fBeXh

Taşseven, Ö. and Çınar, S. (2015). Türkiye'de Borç Dolarizasyonunun Belirleyicileri ve Makroekonomik Göstergeler Üzerindeki Etkileri. Sosyal Bilimler Araştırma Dergisi 4(2), 121-141.

Yurttançıkmaz, Z. Ç. (2014). Seçilmiş Ülkelerde Rekabet Gücünün Belirleyicileri ve Büyüme İlişkileri. Yayımlanmamış Doktora Tezi, Erzurum Atatürk Üniversitesi.

Yurttançikmaz, Z. Ç., Kabadayi, B. and Emsen, Ö. S. (2014). Ekonomik Büyüme ve Rekabet Gücü Üzerine Türkiye Analizi. Ekonometri ve Istatistik Dergisi, 21, 21-46. 